\title{
Exhaust Gas Emission Improvements of Water/Bunker C Oil-Emulsified Fuel Applied to Marine Boiler
}

\author{
Tae-Ho Lee ${ }^{1}$, Sang-Hyun Lee ${ }^{2}$ and Jee-Keun Lee ${ }^{3, *}$ \\ 1 Department of Power Plant, Korea Polytechnic College, Muan 58542, Korea; leeth@kopo.ac.kr \\ 2 Greentech Co., Ltd., Jeongeup 56137, Korea; smsh8845@naver.com \\ 3 Department of Mechanical System Engineering, Jeonbuk National University, Jeonju 54896, Korea \\ * Correspondence: jklee@jbnu.ac.kr; Tel.: +82-63-270-2369
}

check for updates

Citation: Lee, T.-H.; Lee, S.-H.; Lee, J.-K. Exhaust Gas Emission Improvements of Water/Bunker C Oil-Emulsified Fuel Applied to Marine Boiler. J. Mar. Sci. Eng. 2021, 9 , 477. https://doi.org/10.3390/ jmse9050477

Academic Editor: Tie Li

Received: 22 March 2021

Accepted: 26 April 2021

Published: 29 April 2021

Publisher's Note: MDPI stays neutral with regard to jurisdictional claims in published maps and institutional affiliations.

Copyright: (C) 2021 by the authors. Licensee MDPI, Basel, Switzerland. This article is an open access article distributed under the terms and conditions of the Creative Commons Attribution (CC BY) license (https:/ / creativecommons.org/licenses/by/ $4.0 /)$.

\begin{abstract}
In this study, emulsified fuels were prepared and produced by blending $0 \%, 5 \%, 15 \%$, and $25 \%$ water with Bunker $\mathrm{C}$ oil to reduce the amount of air pollution emitted by ships and replace oil resources, and they were applied to an actual marine boiler to analyze the exhaust gas. The fuel effects on the improvement in exhaust gas emissions were as follows: The oxygen $\left(\mathrm{O}_{2}\right)$ concentration increased by up to $4.2 \%$, and that of carbon dioxide decreased by approximately $2.1 \%$. Under the standard $\mathrm{O}_{2}$ concentration of $4 \%$, the concentration of nitrogen oxides decreased by up to $31.41 \%$, and that of sulfur oxides decreased by up to $37.47 \%$. However, the exhaust gas temperature decreased by approximately $14.3 \%$, and the combustion efficiency decreased by approximately $2.6 \%$. Comparing the emission improvements, the combustion performance of the emulsified fuels was close to that of the conventional Bunker $C$ fuel. These results indicate that the application of water-emulsified fuels to a marine boiler can reduce the amounts of certain air pollutants.
\end{abstract}

Keywords: emulsified oil; marine boiler; Bunker C; exhaust emissions; International Maritime Organization; nitric oxide; sulfur oxide; carbon dioxide

\section{Introduction}

Fossil fuels represent $80 \%$ of the global energy supply; however, discoverable oil resources are expected to decrease. According to one report, global oil production is expected to reach its peak in 2020 and then rapidly decrease [1]. Figure 1 displays the global oil production forecast based on the current scenario [2]. In addition, approximately $65 \%$ of global oil reserves are being produced in Middle Eastern countries [3], and this is expected to accelerate the supply-demand imbalance of nonproducing countries, as they are highly dependent on oil imports.

The consumption of alternative energy sources is expected to slowly increase due to the depletion of oil resources. In addition to shortages of coal and oil resources, this is because of serious environmental pollution caused by the exhaust gas from fossil energy use and the enforcement of strict emission regulations by various countries.

Exhaust gas emitted by ships in particular exhibits severe pollution levels. According to a report from the International Maritime Organization (IMO), nitrogen oxides $\left(\mathrm{NO}_{\mathrm{x}}\right)$, sulfur oxides $\left(\mathrm{SO}_{\mathrm{x}}\right)$, and carbon dioxide $\left(\mathrm{CO}_{2}\right)$ emissions from ships account for $14 \%, 5 \%$, and $2 \%$ of global emissions from transportation, respectively [4].

Therefore, the IMO requires the use of fuels with low sulfur contents or engines that meet the allowed $\mathrm{NO}_{\mathrm{x}}$ emission threshold specified by the IMO to regulate ship exhaust gas emissions [5].

To satisfy these emission regulations, after installing separate exhaust gas reduction devices in existing combustion systems, the fuel is pretreated by applying alternative energy sources. Regarding representative post-treatment systems, exhaust gas recirculation, selective catalytic reduction, and diesel particulate filter methods are the most widely utilized exhaust gas reduction approaches [6]. 
Despite the continuous efforts required for the retrofitting of flue-gas treatment plants, research is trying to offer increasingly efficient solutions that are adaptable to stringent IMO requests and at the same time less and less impactful from the point of view of costs and space required for shipboard installations [7-9].

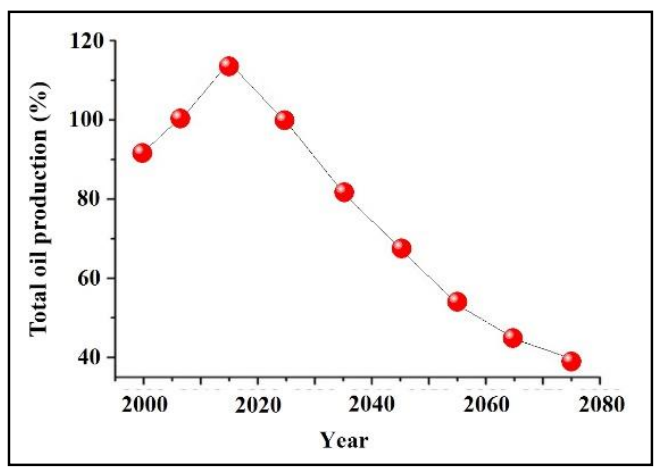

Figure 1. World oil production forecast based on present demand scenario.

However, installing these systems does not address the problem of fuel consumption, and it is difficult for the systems to improve the maintenance cost problem because the mechanical system structure must be modified, and regular maintenance is required [3].

Various studies have been conducted to improve these mechanical technologies and develop alternative energy sources that do not require separate reduction systems. Representative research fields include the biodiesel field, in which bioresources are applied to diesel oil; the dimethyl ether field; and the emulsion field, which blends materials [10].

These alternative energy sources advantageously produce outputs similar to those of conventional fuels while also reducing air pollution, and they do not modify the mechanical system structure. Various studies have been conducted on emulsified fuels, primarily in advanced countries, because exhaust gas has been improved by physically blinding water and fuel [11].

Kim et al. found that an emulsified fuel created by blending water with diesel oil reduced the $\mathrm{NO}_{x}$ and soot in a 2456-cc diesel engine [12]. Lim et al. researched the combustion characteristics of emulsified fuels in a ship diesel engine and reduced $\mathrm{NO}_{\mathrm{x}}$ emissions by approximately $30 \%$, depending on the water content $[13,14]$. In these studies, fuels created by blending water and diesel oil were applied to diesel engines, and other studies have been conducted under similar conditions $[15,16]$.

Park et al. simultaneously injected water and diesel oil into a hybrid boiler burner to compensate for water and diesel oil separation, demonstrating that $\mathrm{NO}_{\mathrm{x}}$ emissions can be reduced by up to $45.5 \%$ [17]. Similar to our study, Chung applied a mixture of Bunker C oil, low-quality fuel, and livestock wastewater to a boiler and reported that the exhaust gas temperature was reduced by approximately $100^{\circ} \mathrm{C}$, and certain air pollutants were reduced [18].

In previous studies conducted by the authors of this study, emulsified fuel created by blending approximately $10.6 \%$ water with Bunker $\mathrm{C}$ oil was applied to a gun-type industrial boiler burner, and $\mathrm{NO}_{\mathrm{x}}$ and $\mathrm{SO}_{\mathrm{x}}$ emissions were reduced by approximately $30 \%[19,20]$. Therefore, in this study, emulsified fuels created by blending water with Bunker $\mathrm{C}$ oil were applied to an actual marine boiler to analyze their effects on $\mathrm{NO}_{\mathrm{x}}, \mathrm{SO}_{\mathrm{x}}$, and $\mathrm{CO}_{2}$ emissions, which are typical exhaust gas emissions.

\section{Materials and Methods}

The emulsified fuels used in this study were produced using dedicated plant equipment capable of instantaneous automatic production, and the production process occurred in seven steps. Figure 2 displays the plant equipment, and Figure 3 illustrates the seven steps of the production process [21]. 


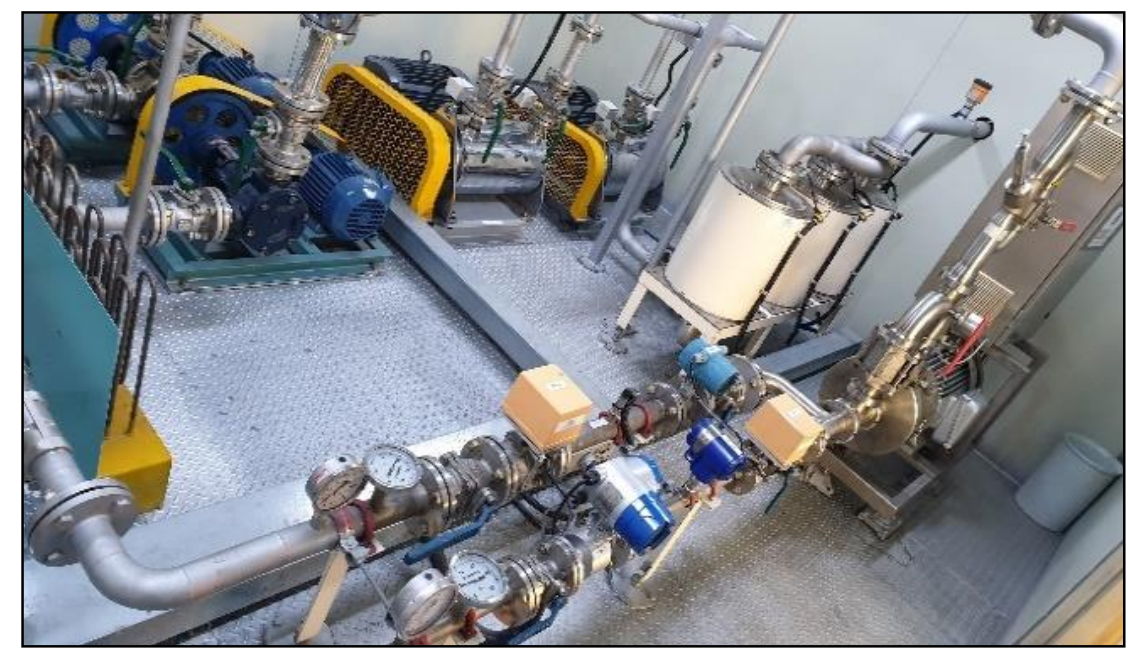

Figure 2. Photograph of emulsification equipment [21].

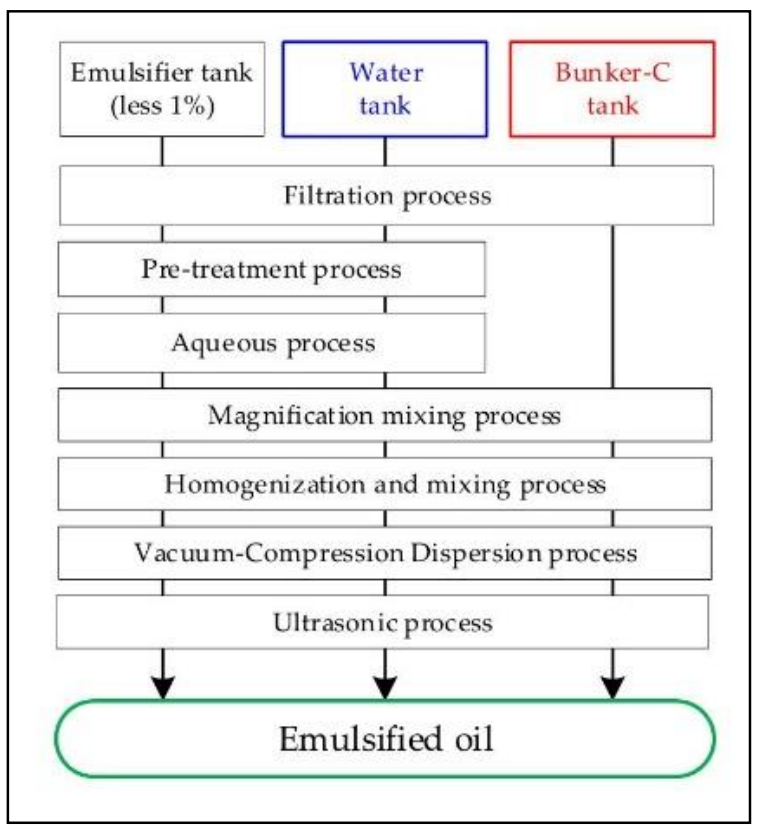

Figure 3. Seven-step production process.

Each storage tank was installed before the supply pipe of the plant equipment. Water, Bunker C oil, and a small amount of emulsifier (less than 1\%) were secured, and each fluid was subjected to filtration as the first step. After the second step pretreatment process where water and emulsifier were blended, an emulsified aqueous solution was prepared in the third step. The mixing ratio with Bunker $C$ oil was then set via the fourth step magnification mixing process in which the producer set the water content of the emulsified aqueous solution between $0 \%$ and $25 \%$. In the fifth step, the oil and water were preheated to approximately $60^{\circ} \mathrm{C}$, which is appropriate for mixing, to improve the mixing quality, and homogenization and flash mixing were performed using ultra-high-speed rotation between 10,000 rpm and 30,000 rpm. Afterward, the emulsion was stabilized using vacuum compression dispersion. Finally, in the seventh step ultrasonic process, various sludge lumps present in the Bunker C oil, which is a low-quality fuel, were finely crushed to improve the oil quality.

In this study, four water contents were used for production. The set water contents were $0 \%, 5 \%, 15 \%$, and $25 \%$, and the names of the fuels were set to EM0, EM5, EM15, and EM25, respectively. Figure 4 compares water-emulsified fuel samples produced using 
various fuel types (marine diesel oil, marine gas oil, and diesel oil). The other emulsified fuel types were a lighter brown than the pure Bunker $C$ oil with a water content of $0 \%$, and there was no significant difference in color between the Bunker $C$ oils with different water contents based on visual inspection.

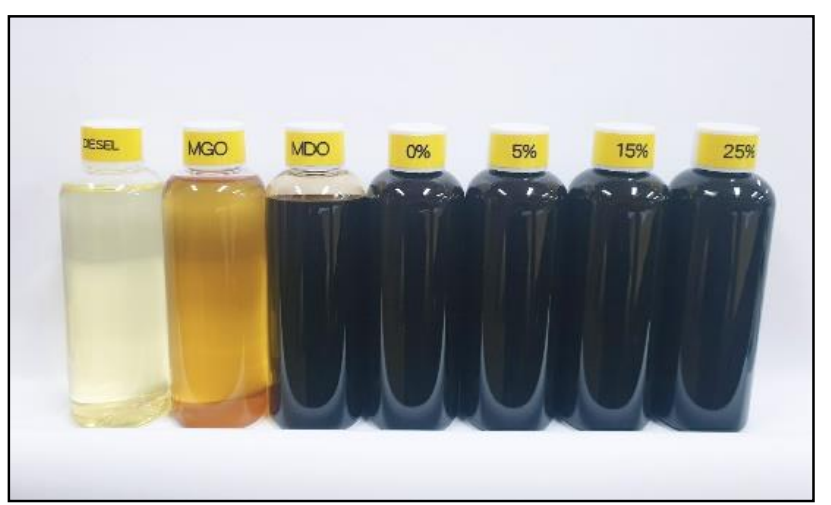

Figure 4. Comparison of water-emulsified oil samples.

To investigate the component characteristics of the produced emulsified fuels, the fuels were analyzed following the International Organization for Standardization (ISO) 8217 , a standard test method for ship fuel oil. Table 1 lists the analysis items and details of the standard test [3].

Table 1. ISO 8217 fuel component analysis methods.

\begin{tabular}{ccc}
\hline List & Method & Unit \\
\hline Water content & KS M ISO 3733:2008 & Vol, \% \\
Sulfur content & KS M ISO 2414:2011 & $\mathrm{m} / \mathrm{m}, \%$ \\
Flash point & KS M ISO 2592:2007 & ${ }^{\circ} \mathrm{C}$ \\
Gravity API @ $60^{\circ} \mathrm{F}$ & KS M ISO 12185:2003 & - \\
S.G @ 15 $/ 4^{\circ} \mathrm{C}$ & & - \\
\hline
\end{tabular}

The produced emulsified fuels were applied to the marine boiler VWH-600 [22], a device approved by the Korean Register, an approval agency in South Korea [23].

Figure 5 displays the boiler used in the actual experiment, and its detailed specifications are listed in Table 2. The operation of the boiler was applied by changing only the fuel composition under the same conditions as the Bunker $\mathrm{C}$ fuel.

Table 2. Marine boiler specifications.

\begin{tabular}{ccc}
\hline List & Specification & Unit \\
\hline Model & VWH-600 & - \\
Evaporation & 600 & $\mathrm{~kg} / \mathrm{h}$ \\
Calorific Value & 323,300 & $\mathrm{kcal} / \mathrm{h}$ \\
Fuel consumption & Max. 39.0 & $\mathrm{~kg} / \mathrm{h}$ \\
Steam pressure & Max. 10.0 & $\mathrm{~kg} / \mathrm{cm}^{2}$ \\
Burner & Pressure atomizing type & - \\
Electrical capacity & Max. 6.8 & $\mathrm{kw}$ \\
Weight (dry) & 2140 & $\mathrm{~kg}$ \\
\hline
\end{tabular}




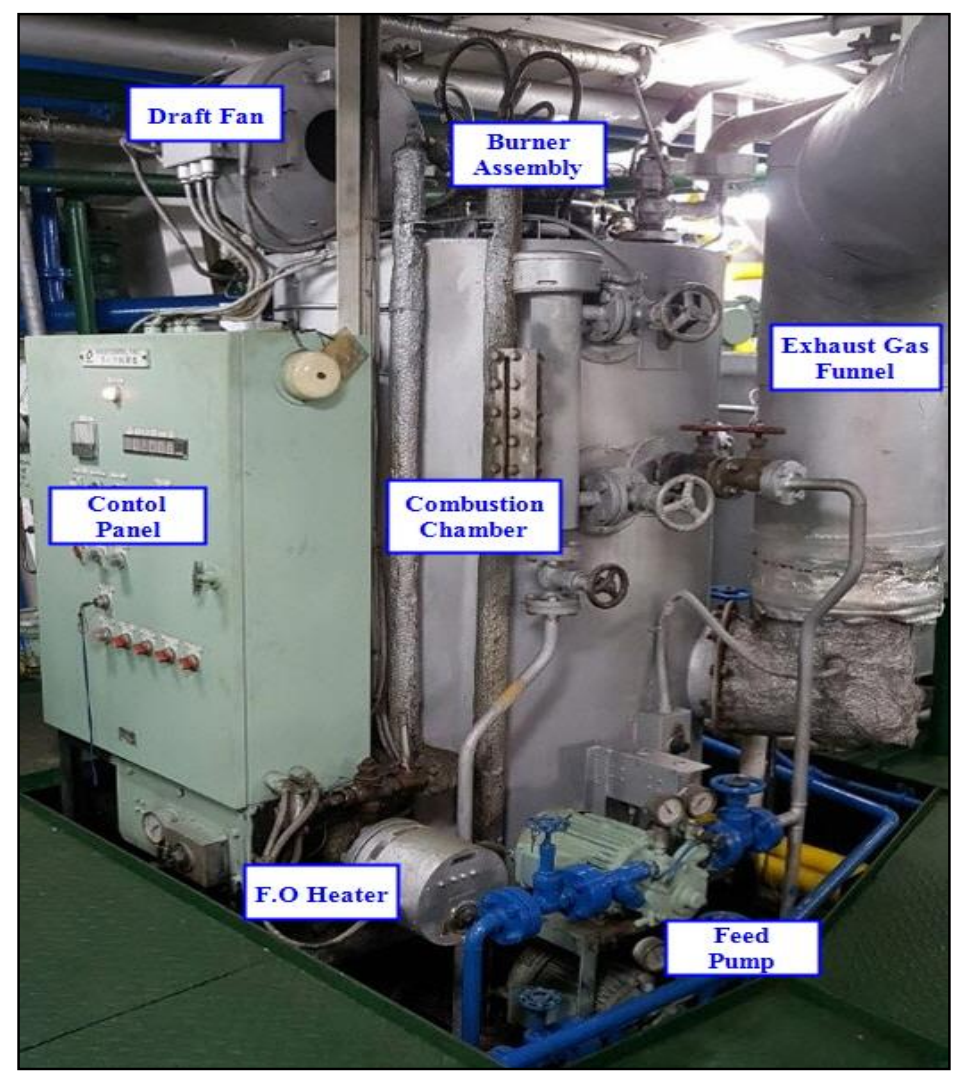

Figure 5. Photograph of marine boiler assembly.

TESTO-340 was selected as the gas analyzer for the exhaust gas measurements [24]. The measurement items were the oxygen $\left(\mathrm{O}_{2}\right)$ content, $\mathrm{CO}_{2}, \mathrm{NO}_{\mathrm{x}}, \mathrm{SO}_{\mathrm{x}}$, and exhaust gas temperature $\left({ }^{\circ} \mathrm{C}\right)$. The detailed specifications are listed in Table 3.

$\mathrm{NO}_{x}$ and $\mathrm{SO}_{x}$ emissions were continuously measured for 5 min per the Korea National Institute of Environmental Research (NIER) air pollution process test standards [25] to obtain their average values, and this procedure was repeated three times to determine the total average values. For $\mathrm{SO}_{\mathrm{x}}$, however, only sulfur dioxide $\left(\mathrm{SO}_{2}\right)$ was measured based on the test standard, and the measurement method is presented in Table 4 . When the fuel was changed, measurements were performed after approximately $1 \mathrm{~h}$ to ensure sufficient replacement of the residual fuel and stabilization of combustion.

Table 3. Gas analyzer specification [20].

\begin{tabular}{cccc}
\hline Parameter & Range & Unit & Resolution \\
\hline $\mathrm{O}_{2}$ & $0-25.0$ & Vol, \% & 0.01 \\
$\mathrm{CO}_{2}$ & $0-15.8$ & Vol, \% & 0.1 \\
$\mathrm{NO}_{\mathrm{x}}$ & $0-4000$ & $\mathrm{ppm}$ & 1 \\
$\mathrm{SO}_{2}$ & $0-5000$ & $\mathrm{ppm}$ & 1 \\
Temperature & $-40-1200$ & ${ }^{\circ} \mathrm{C}$ & 0.1 \\
\hline
\end{tabular}

Table 4. NIER air pollution process test method [24].

\begin{tabular}{cccc}
\hline Parameter & Range & Unit & Method \\
\hline $\mathrm{NO}_{\mathrm{x}}$ & $0-1000$ & $\mathrm{ppm}$ & Average value of three \\
$\mathrm{SO}_{\mathrm{x}}$ & $0-1000$ & $\mathrm{ppm}$ & $\begin{array}{c}\text { consecutive measurements } \\
\text { every } 5 \text { min. }\end{array}$ \\
\hline
\end{tabular}


Figure 6 displays a schematic of the experiment used in this study. The experimental setup consisted of two separate fuel tanks, and the replacement of the emulsified fuel and Bunker $C$ oil can be freely changed using a three-way valve. They were supplied to the boiler after preheating through an electricity-powered coil heater. In addition, because the boiler operation was automatically stopped when the boiler feed water reached the evaporation pressure, the open-loop method was used instead of the closed-loop circulation method to ensure the continuous supply and discharge of feed water, considering the nature of the experiment, which requires long-term operation.

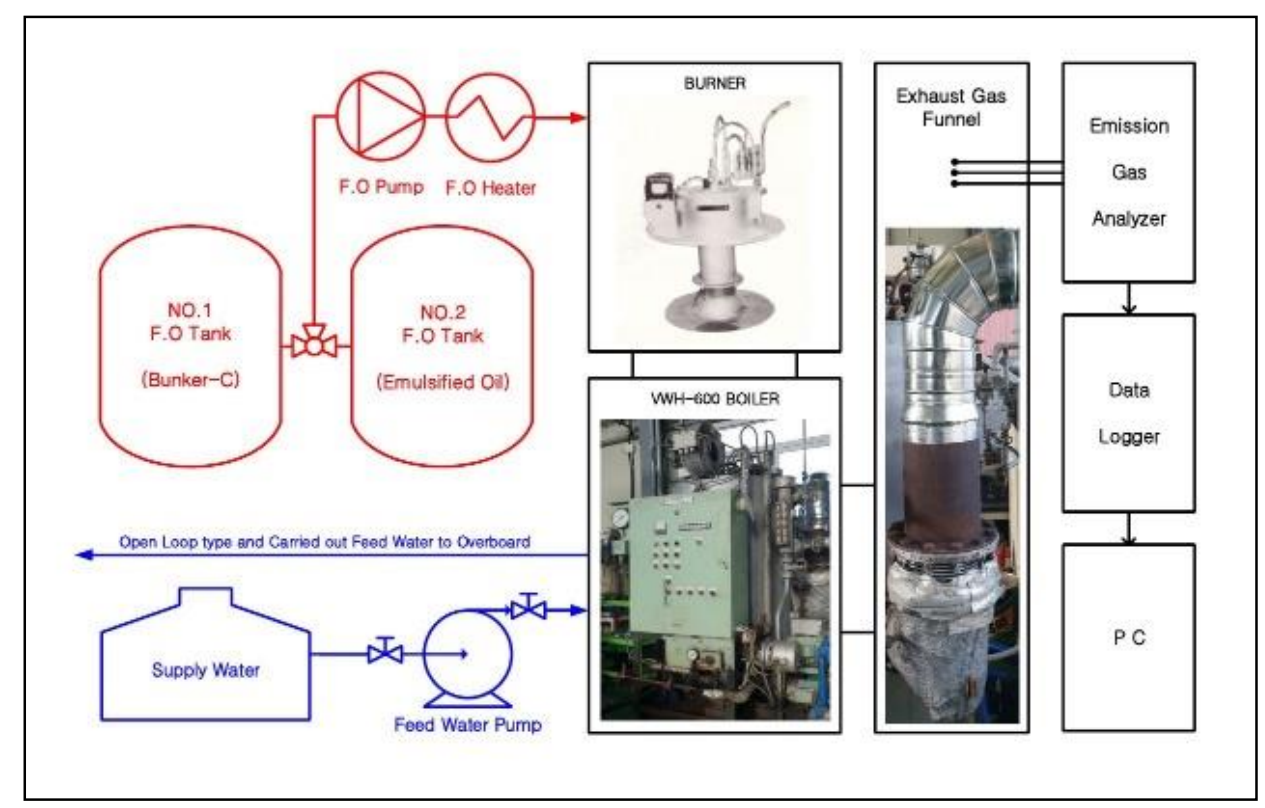

Figure 6. Schematic of experimental apparatus.

\section{Results and Discussion}

\subsection{Component Characteristics of Emulsified Fuels}

Figure 7 illustrates the component characteristics of the water/Bunker C oil-emulsified fuels produced for the experiment in this study.

The water contents were 25.0\% for EM25, 15.0\% for EM15, 5.0\% for EM5, and approximately $0.6 \%$ for EM0, respectively. The sulfur content of the Bunker C oil selected for the experiment was less than $0.3 \%$, indicating that the oil was a low-sulfur fuel. The component analysis results demonstrated that the sulfur content decreased from $0.28 \%$ to $0.20 \%$ as the water content increased. This percentage reduction is due to the dilution by water per unit volume.

The specific weight ranged from 0.9471 to 0.9382 , and this can be considered the difference in the specific gravity of water due to the increase in water content. The flash point ranged from $172{ }^{\circ} \mathrm{C}$ to $101{ }^{\circ} \mathrm{C}$. This result satisfies the minimum condition of $60{ }^{\circ} \mathrm{C}$ or higher for Bunker $\mathrm{C}$ oil; however, it is impossible to measure the flash point due to the boiling phenomenon in which the water contained in the fuel reaches $100^{\circ} \mathrm{C}$. Analytical laboratories typically suggested that the conditions were satisfied, and they predicted that the actual flash point exceeded $172{ }^{\circ} \mathrm{C}$, which is that of EM0. 


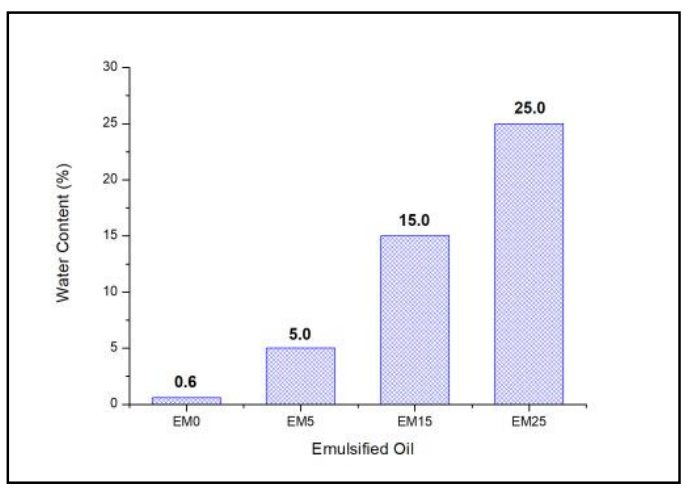

(a)

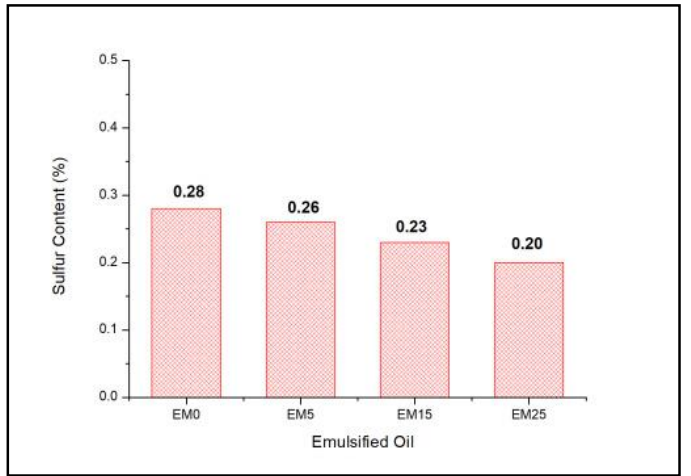

(b)

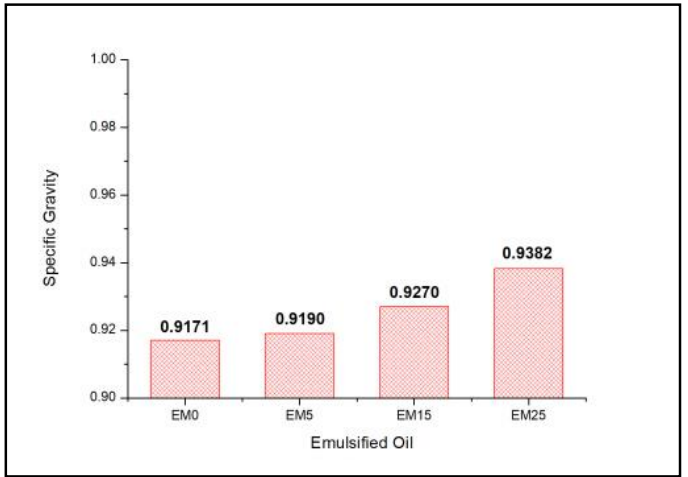

(c)

Figure 7. Fuel composition comparison of emulsified oils: (a) water content, (b) sulfur content, and (c) specific gravity.

\subsection{Exhaust Gas Emission Characteristics}

Figure 8 displays the characteristics of the exhaust gas emissions measured during the combustion process. The $\mathrm{O}_{2}$ content was $6.20 \%$ for EM0, which is the pure Bunker C oil, $7.51 \%$ for EM5, 8.82\% for EM15, and $10.40 \%$ for EM25, increasing $\mathrm{O}_{2}$ content by up to $4.20 \%$.

This result appears to be due to the $\mathrm{O}_{2}$ dissolved in the water that was contained in the emulsified fuels and the unburned content of the air supplied to the boiler. The $\mathrm{CO}_{2}$ content (\%) was $11.1 \%$ for EM0, 10.2\% for EM5, 9.2\% for EM15, and 8.0\% for EM25, demonstrating a reduction in the $\mathrm{CO}_{2}$ content by up to $2.1 \%$ within the scope of this study.

The $\mathrm{NO}_{\mathrm{x}}$ concentrations were $129.7 \mathrm{ppm}$ for EM0 and $63.7 \mathrm{ppm}$ for EM25, exhibiting a reduction of up to $50.9 \%$. This appears to be because the $\mathrm{NO}_{\mathrm{x}}$ concentration increases in high-temperature areas of exhaust gas, and it was therefore affected by the reduction in the exhaust gas temperature caused by the latent evaporation heat of the water contained in the emulsion. 


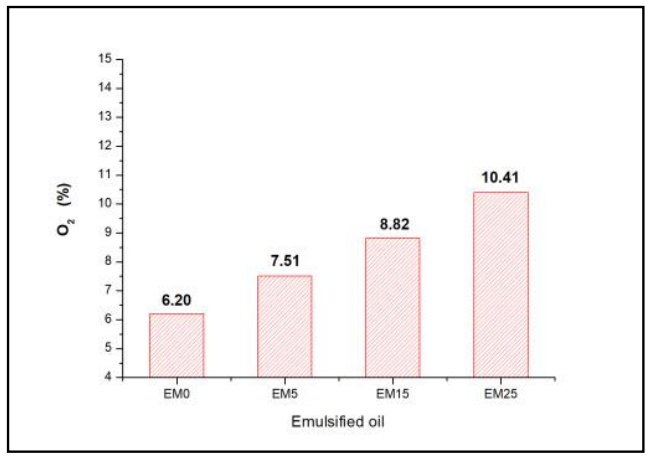

(a)

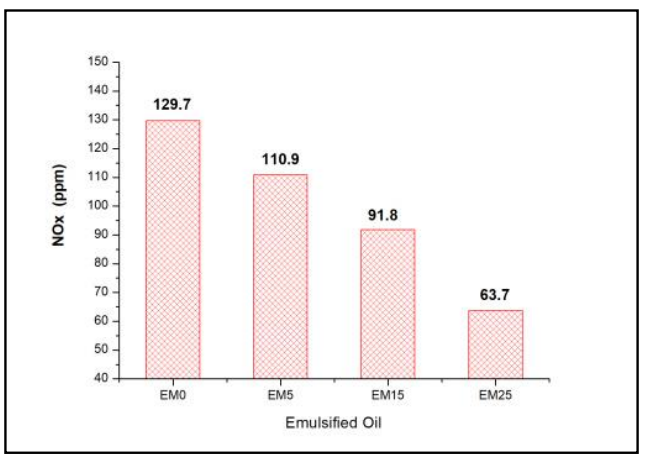

(c)

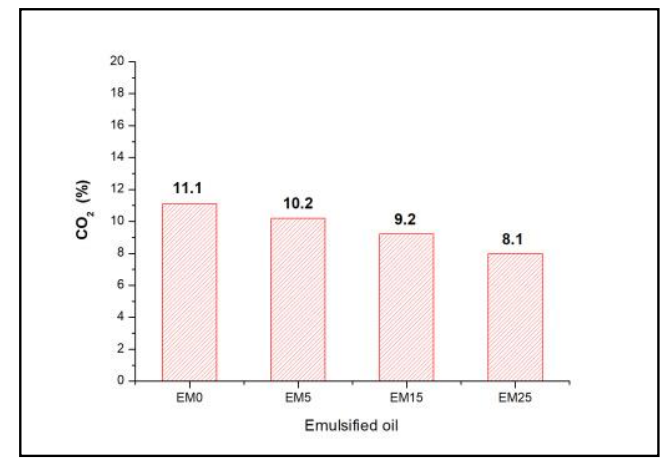

(b)

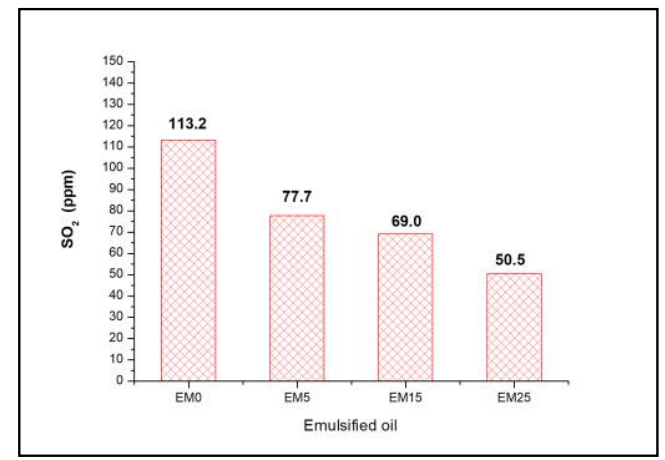

(d)

Figure 8. Exhaust gas emissions comparison of emulsified oil: (a) $\mathrm{O}_{2},(\mathbf{b}) \mathrm{CO}_{2}$, (c) $\mathrm{NO}_{\mathrm{x}}$, and (d) $\mathrm{SO}_{2}$.

The $S O_{x}$ concentration significantly decreased by approximately $62.7 \%$ from $113.2 \mathrm{ppm}$ for EM0 to $50.5 \mathrm{ppm}$ for EM25. This is because the sulfur content per unit volume of the fuel was reduced by an increased water content [19]. As the $\mathrm{NO}_{x}$ and $\mathrm{SO}_{x}$ concentrations were the actual measured values, and the $\mathrm{O}_{2}$ concentration varied, their reduction effects were calculated by applying a $4 \% \mathrm{O}_{2}$ concentration correction factor, which is the standard $\mathrm{O}_{2}$ concentration. This is because the generated exhaust gas was diluted using different amounts of supply air, depending on the fuel.

$$
\begin{aligned}
& N O_{x}[p p m, 4 \%]=N O_{x a} \times \frac{O_{2 r e f}-O_{2 s}}{O_{2 r e f}-O_{2 a}} \\
& S O_{x}[p p m, 4 \%]=S O_{x a} \times \frac{O_{2 r e f}-O_{2 s}}{O_{2 r e f}-O_{2 a}}
\end{aligned}
$$

Therefore, the standard $\mathrm{O}_{2}$ concentration of $4 \%$ can be applied to Equations (1) and (2). Here, $N O_{x a}$ and $S O_{x a}$ are the measured $\mathrm{NO}_{x}$ and $\mathrm{SO}_{x}$ data, respectively. $\mathrm{O}_{2 r e f}$ is the $\mathrm{O}_{2}$ concentration of $21 \%$ in the atmosphere, $\mathrm{O}_{2 s}$ is the standard $\mathrm{O}_{2}$ concentration of $4 \%$, and $\mathrm{O}_{2 a}$ is the actual measured $\mathrm{O}_{2}$ concentration.

Figure 9 displays the $\mathrm{NO}_{x}$ and $\mathrm{SO}_{x}$ results obtained by applying the standard $\mathrm{O}_{2}$ concentration. The $\mathrm{NO}_{x}$ concentration decreased by up to $31.41 \%$ from $148.93 \mathrm{ppm}$ for EM0 to $102.15 \mathrm{ppm}$ for EM25, and the $S O_{x}$ concentration decreased by up to $37.47 \%$ from $130.0 \mathrm{ppm}$ for EM0 to $81.3 \mathrm{ppm}$ for EM25. 


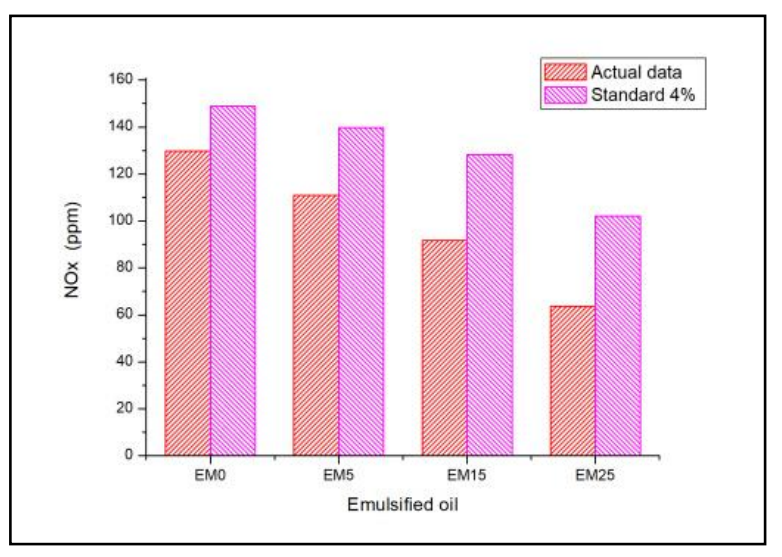

(a)

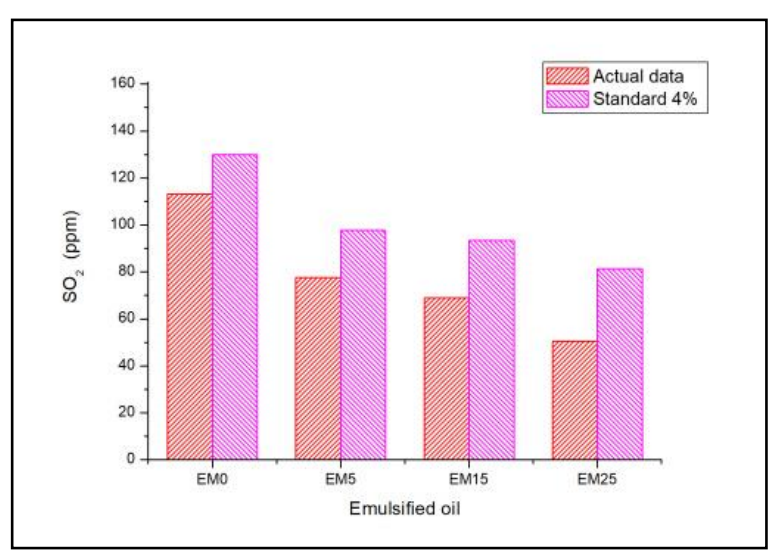

(b)

Figure 9. Emission comparison of emulsified oils when standard $\mathrm{O}_{2} 4 \%$ was applied: (a) $\mathrm{NO}_{\mathrm{x}}$ and (b) $\mathrm{SO}_{2}$.

\subsection{Exhaust Gas Temperature Characteristics}

The exhaust gas temperature decreased as the water content increased in the emulsified fuels. Figure 10 shows the exhaust gas temperature results. The exhaust temperature showed a tendency to decrease by up to approximately $14.3 \%$ within the experimental range of this study, as it was found to be $319.9^{\circ} \mathrm{C}$ for EM0, which is pure Bunker C oil without water, and $274.1^{\circ} \mathrm{C}$ for EM25. This appears to be due to the temperature reduction caused by the latent heat of evaporation of the water contained in the fuel and the temperature reduction caused by the increase in the amount of excess air.

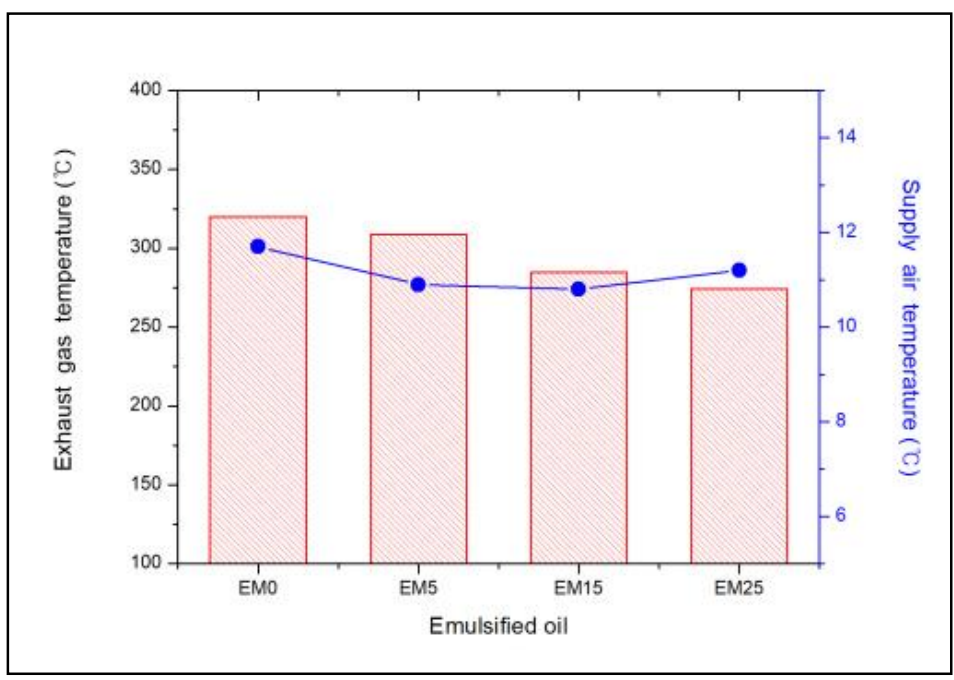

Figure 10. Exhaust gas temperature comparison of emulsified oils.

\subsection{Combustion Efficiency}

The combustion efficiency was calculated by applying the experimental results of exhaust gas emissions. The formula used to calculate the combustion efficiency is displayed in Equation (3). $q A$ is the combustion efficiency (\%), and $f$ is the specific fuel constant for heavy oils, such as Bunker $C$ fuel. $T_{g a s}$ is the exhaust gas temperature, and $T_{a m b}$ is the supply air temperature. These two temperature differences were divided by $\mathrm{CO}_{2}$ to obtain the combustion efficiency.

$$
q A[\%]=100 \times \frac{f \times\left(T_{\text {gas }}-T_{a m b}\right)}{\mathrm{CO}_{2}},
$$


The combustion efficiency decreased as the water content increased in the emulsified fuels. Figure 11 presents the combustion efficiency results. The combustion efficiency exhibited a decreasing tendency by up to approximately $2.6 \%$ within the experimental range of this study; it was $85.84 \%$ for EM0, which is pure Bunker C oil without water, and 83.24\% for EM25.

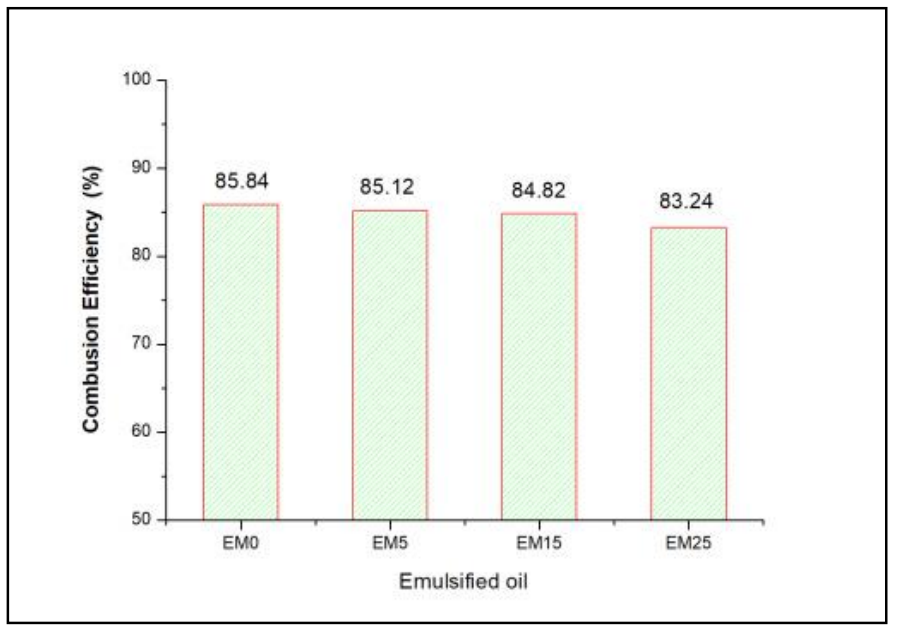

Figure 11. Combustion efficiency comparison of emulsified oils.

\section{Conclusions}

In this study, the emulsified fuels produced by blending water with Bunker $C$ oil were applied to a marine boiler, and their effects on exhaust gas emissions were analyzed. The following conclusions can be drawn:

(1) The $\mathrm{O}_{2}$ concentration was $6.2 \%$ for EM0 and $10.4 \%$ for EM25, demonstrating an increase of $4.2 \%$.

(2) The $\mathrm{CO}_{2}$ concentration decreased by $2.1 \%$; it was $11.1 \%$ for EM0 and $8.0 \%$ for EM25.

(3) The actual measured $\mathrm{NO}_{x}$ concentration decreased by up to $50.9 \%$, and it decreased by up to $31.41 \%$ when a standard $\mathrm{O}_{2}$ concentration of $4 \%$ was applied.

(4) The $\mathrm{SO}_{x}$ concentration decreased by up to $62.7 \%$, and it decreased by up to $37.47 \%$ when a standard $\mathrm{O}_{2}$ concentration of $4 \%$ was applied.

(5) The exhaust gas temperature exhibited a decreasing tendency by approximately $14.3 \%$ when the water content was $25 \%$, which was the maximum condition of this study.

(6) The combustion efficiency exhibited a decreasing tendency by approximately $2.6 \%$ when the water content was $25 \%$, which was the maximum condition of this study.

Because the marine boiler applied in this study is a fixed operating condition where proportional control of the supply air volume is not possible, the emission gas reduction effect can be further improved if applied to a boiler capable of proportional control. Therefore, a future experimental study can apply emulsified fuel to a rotary-cup marine boiler that can automatically control the optimal combustion.

Author Contributions: Conceptualization, T.-H.L.; Funding acquisition, S.-H.L.; Investigation, S.-H.L.; Methodology, T.-H.L.; Project administration, J.-K.L.; Resources, T.-H.L.; Supervision, J.-K.L.; Visualization, T.-H.L.; Writing—original draft, T.-H.L.; Writing—review \& editing, T.-H.L. All authors have read and agreed to the published version of the manuscript.

Funding: This research received no external funding.

Institutional Review Board Statement: Not applicable.

Informed Consent Statement: Not applicable.

Data Availability Statement: Not applicable.

Conflicts of Interest: The authors declare no conflict of interest. 


\section{References}

1. Demirbas, A. Biodiesel: A Realistic Fuel Alternative for Diesel Engines; Springer: London, UK, 2008.

2. Mohd, N.C.W.; Noor, M.M.; Mamat, R. Biodiesel as alternative fuel for marine diesel engine applications: A review. Renew. Sustain. Energy Rev. 2018, 94, 127-142. [CrossRef]

3. Lee, T.H. A Study on the Characteristics of Exhaust Emissions in a Marine Boiler Using Emulsified Bunker-C Oil; Jeonbuk National University: Jeonju, Korea, 2020.

4. Force, C.A.T. Prevention of Air Pollution from Ships: Reducing Shipping Emissions of Air Pollution-Feasible and Cost-Effective Options Submitted by Friends of the Earth International to the Marine Environment Protection Committee; International Maritime Organization: London, UK, 2005.

5. Choi, J.S.; Han, S.G.; Choi, J.H.; Park, S.K.; Park, R.S.; Kim, D.H. A Study on Characteristics of Exhaust Gas Emissions of Water-Bunker Oil Mixed by Homogenizer. J. Korean Soc. Mar. Environ. Saf. 2013, 19, 518-524. [CrossRef]

6. Son, J.H.; Kim, J.H.; Jung, S.W.; Yoo, H.M.; Hong, H.K.; Mun, S.H.; Choi, K.H.; Lee, J.T.; Kim, J.S. Characteristics of Air Pollutants Emission from Medium-duty Trucks Equipped EGR and SCR in Korea. J. ILASS-Korea 2016, 21, 130-136. [CrossRef]

7. Flagiello, D.; Parisi, A.; Lancia, A.; Carotenuto, C.; Erto, A.; Di Natale, F. Seawater desulphurization scrubbing in spray and packed columns for a 4.35 MW marine diesel engine. Chem. Eng. Res. Des. 2019, 148, 56-67. [CrossRef]

8. Flagiello, D.; Di Natale, F.; Carotenuto, C.; Erto, A.; Lancia, A. Seawater Desulphurization of Simulated Flue Gas in Spray and Packed Columns: An Experimental and Modelling Comparison. Chem. Eng. Trans. 2018, 69, 799-804. [CrossRef]

9. Flagiello, D.; Di Natale, F.; Erto, A.; Lancia, A. Wet oxidation scrubbing (WOS) for flue-gas desulphurization using sodium chlorite seawater solutions. Fuel 2020, 277, 118055. [CrossRef]

10. Yoon, J.H.; Yeom, J.K. Numerical Analysis on Behavior Characteristics of Evaporative Spray of Emulsified Fuel Impinging on a Heated Flat Plate. Trans. KSME-B 2019, 43, 471-477. [CrossRef]

11. No, J.M. Combustion Characteristics of Steam Boiler Using Heavy Oil/Emulsified Fuel; Ajou University: Suwon, Korea, 2008.

12. Kim, M.C.; Lee, C.S. It's effects for engine emission of water/oil emulsified fuel. Anal. Sci. Technol. 2008, 21, 156-166.

13. Lim, J.K.; Cho, S.G.; Hwang, S.J.; Yoo, D.H. Effect on Characteristics of Exhaust Emissions by Using Emulsified Fuel in Diesel Engine. J. Korean Soc. Mar. Eng. 2007, 31, 44-50. [CrossRef]

14. Lim, J.K.; Cho, S.G.; Hwang, S.J.; Yoo, D.H. Effects on Characteristics of Combustion by Using Emulsified Fuel in Diesel Engine. J. Korean Soc. Mar. Eng. 2007, 31, 51-55.

15. Lim, H.K.; Lee, M.J.; Chi, G.Y.; Lim, J.C. Emission Evaluation of Emulsified fuel Prepared from Bunker C Oil. Appl. Chem. Eng. 2017, 28, 186-192. [CrossRef]

16. Gollahalli, S.R.; Nasrullah, M.K.; Bhashi, J.H. Combustion and Emission Characteristics of Burning Sprays of a Residual Oil and Its Emulsion with Water. Combust. Flame 1984, 55, 93-103. [CrossRef]

17. Park, K.H.; Kim, D.K.; Kim, C.J. Burner Combustion Characteristics of Hybrid Type Water Mixing Emulsified fuel. J. Korean Soc. Mar. Eng. 2013, 37, 308-315. [CrossRef]

18. Chung, J.D. An Experimental Study on the Combustion Characteristics of Wastewater-Emulsified fuel. J. Energy Eng. 2003, 12, 267-273.

19. Lee, T.H.; Lee, J.K. An Experimental Study on the $\mathrm{SO}_{2}$ Reduction of Water $10 \%$ Mixed Emulsified Oil Applied to Boiler-Burner Using Bunker-C Oil. J. Fish. Mar. Sci. Educ. 2019, 31, 1801-1807. [CrossRef]

20. Lee, T.H.; Lee, J.K. An Experimental Study on the $\mathrm{NO}_{\mathbf{x}}$ Reduction of Emulsified Oil Applied to Boiler-Burner Using Bunker C Oil. J. Korean Soc. Mech. Technol. 2019, 21, 1071-1076. [CrossRef]

21. Lee, T.H.; Lee, J.K. Manufacturing and Component Characteristics of Emulsified Fuel Oil by Mixing Water-Heavy Oil. J. Korean Soc. Mech. Technol. 2020, 22, 884-890. [CrossRef]

22. MIURA. Z-Boiler Operating Instructions for Marine Use Model VWH; Miura Co. Ltd.: Matsuyama, Japan, 1992.

23. Korea Register (KR). Korean Register of Shipping Certificate Report; No. 294-738-92; Korean Register of Shipping: Busan, Korea, 1992.

24. TESTO. Flue Gas Analyzer Instruction Manual on Testo-340; Testo Co. Ltd.: West Chester, PA, USA, 2016.

25. National Institute of Environmental Research (NIER). Air Pollution Process Test Standard No. 2017-51; National Institute of Environmental Research: Incheon, Korea, 2018. 